\title{
Longitudinal survey of ATB resistance reversibility in children with AIDS of genocide survivors in Cambodia
}

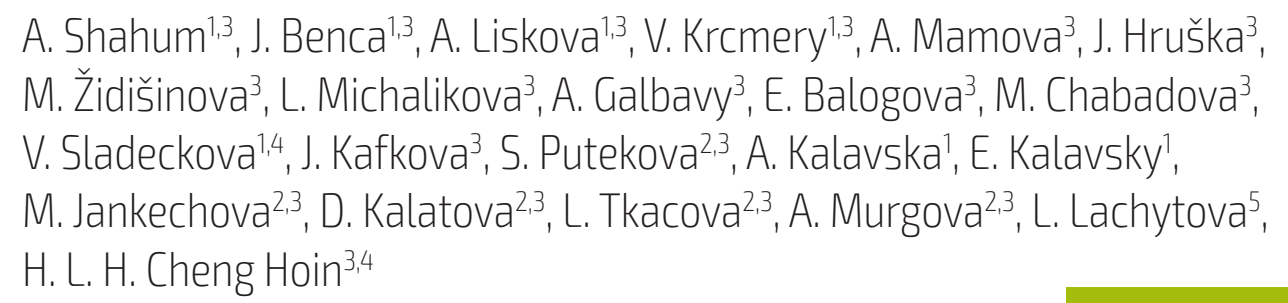

Original Articles

${ }^{1}$ St. Max Kolbe Hospital, House of family, SEU Tropical program, Phnom Phen, Cambodia

${ }^{2}$ St. Ladislavus College and DT Institute Nove Zamky and Michalovce, Slovakia

${ }^{3}$ St. Elizabeth University PhD and MSc Program, Bratislava, Slovakia

${ }^{4}$ House of Hope, SEU Tropical Program Sihanoukville, Cambodia

${ }^{5}$ Internatioal School of Management ISM in Presov, Slovakia

\section{Correspondence to:}

University of North Carolina Chapel Hill School of Medicine, 321 S Columbia St, Chapel Hill, NC 27516, USA

Submitted: 30.6 .2016

Revised: 22.7.2016

Accepted: 3.9 .2016

\section{Reviewers:}

N. Jalili

Institute of Microbiology, Faculty of Medicine and UNB - University Hospital Bratislava, Slovakia J. Mutuku Muli

Institute of Missiology and Tropical Health bl. Pope John Paul II., Polianky, ul. Pod brehmi 4/A, Bratislava, Slovakia

\section{Key words:}

HIV, AIDS, antimicrobial resistance.

\section{Key message:}

ATB, resistance in HIV positive children is reversible.

CSWHI 2016; 7(3): 7-9; DOI 10.22359/cswhi_7_3_01 @ 2016 Clinical Social Work and Health Intervention

\section{Abstract:}

Background: The aim of the survey was to assess antimicrobial resistance dynamics and reversibility in the group of children with AIDS in Cambodia in 2003 - 2015.

Patients: Correlation between antimicrobial (ATB) resistances in commonest respiratory isolates among 140 children with AIDS on antiretroviral therapy was studied from 2003 to 2015 in 586 isolates. 
Results: All but 3 (98\%) children showed a sustained CD4 increase after introduction of antiretroviral therapy (ART) followed by a decrease of ATB resistance. In our group of children restoration of the immune system decreased the number of infection diseases episodes and the proportion of multi-resistant bacterial strains.

Conclusions: Less frequent use of antimicrobial therapy probably led to the decrease of multi-resistance and restoration of susceptibility of studied respiratory bacterial isolates.

\section{Introduction}

Reversibility of ATB resistance has been described on both countrywide and hospital level (1-3), however specific patient groups have been rarely addressed in adults with HIV or Ebola in Sub-Saharan Africa (4-5). Antibiotic resistance is of great concern in patients with AIDS, who are frequently treated with antivirals, antibiotics and anti-tuberculotics for various opportunistic infections. After the introduction of highly active antiretroviral therapy in 1990/2000 most opportunistic infections (OI) decreased. Therefore, also the amount of prophylactically and therapeutically administered antibiotics decreased. Because the amount of antibiotic agents is one of the drivers of ATB resistance, also resistance to antibiotics and anti-tuberculotics should decrease. The aim of this longitudinal research is to determine if resistance of commonest respiratory agents have decreased after the implementation of ART in children in community settings.

\section{Patients and methods}

This longitudinal study includes 12 years (2003-2015) follow up of susceptibility to antibiotics of upper respiratory tract isolates from nose and pharyngeal swabs in children 4-12 years on HAART. 98\% of children showed CD4 increase within 6 months on ART to normal level $>25 \%$ or $>350$ / $\mathrm{mm}^{3}$ ). In the statistical analysis, t-test for trends was used to compare ATB resistance in 2003 to 2015 (EPI INFO version 2014).

\section{Results and discussion}

Table 1 presents trends in ATB resistance in major respiratory isolates from October 2003 to December 2015 (total of 586 isolates). Penicillin resistance in pneumococci decreased from $25 \%$ to $2 \%$ in 2015 ( $\mathrm{P}<0.01$ ); t-test for trends), MRSA from 33.3\% in 2003 to $3 \%$ in 2014 and $2 \%$ in $2015(\mathrm{P}<0.01)$. Erythromycin resistance in Streptococcus pyogenes decreased from $10.5 \%$ in 2003 to $3.3 \%$ in 2015 . At baseline extremely high proportion of ESBL - producing Enterobacteriaceae decreased from $66.6 \%$ to $25 \%$ and such trend was also observed in Candida species and resistance to fluconazole (from $15 \%$ in 2003 to $6 \%$ in 2015).

Reversibility of ATB resistance was documented on the hospital level (2) or on the community national level (1.3), however only in countries with small population (Finland, Denmark, Iceland) with centralized ATB policy. Reversibility time was 2-5 years per country and more (up to 5 years). Reversibility of susceptibility or antibiotic resistance was not yet sufficiently studied in pediatric population with specific immunodeficiency therefore it is deficient to assess, of 10 - 15 years in our group is comparable to e.g. 2 - 5 years on a nation level from Europe (5-8).

\section{Conclusions}

A decrease of the MRSA, PRP, and ESBL producing Enterobacteriaceae and FLU-R in Candida species is in correlation with improved immune status of children with AIDS. Restoration of the immune system with ART led to the CD4 increase and 
was logically followed with less HIV related infections (4). Less antimicrobial agents use is possibly responsible for the phenomenon of the reversibility of antimicrobial resistance also in pathogens colonizing in the respiratory tracts of children with HIV on active antiretroviral therapy.
H, LAGER K, HUOVINEN P.: The effect of changes in the consumption of macrolide antibiotics on erythromycin resistance in group A streptococci in Finland. Finish Study Group for Antimicrobial Resistance. In

6. NEJ Med. 1997. Aug 14; 337 (7): 441-446

Tab. 1 Antimicrobial resistance pathogens among bacteria colonizing the respiratory tract in Cambodian children with HIV.

\begin{tabular}{|l|l|l|l|l|l|l|l|l|l|l|l|l|}
\hline $\mathrm{N}=586$ & 2003 & 2004 & 2005 & 2006 & 2007 & 2009 & 2010 & 2011 & 2012 & 2013 & 2014 & 2015 \\
\hline St. pneumoniae & 25 & 15 & 25,7 & 21,5 & 35,5 & 15,8 & 4,3 & 2,2 & 2,4 & 2,0 & 8 & 2,0 \\
\hline MRSA & 33,3 & 18,5 & 25,7 & 23,1 & 35,5 & 56,6 & 19,1 & 45,1 & 18 & 20,0 & 3,0 & 2,0 \\
\hline Mocca & 12 & 12,3 & 7,3 & 7,7 & 4 & 5,3 & 3,2 & 4,4 & 3,3 & 5,0 & 3,3 & 3,3 \\
\hline HAIN & 8 & 4,6 & 5,8 & 12, & 0,8 & 0 & 1,1 & 1,1 & 2,5 & 6,0 & 4,1 & 3,3 \\
\hline $\begin{array}{l}\text { ERY-R } \\
\text { St. pyogenes }\end{array}$ & 10 & 10,5 & 15,3 & 10 & 12,4 & 10,5 & 8,2 & 5,5 & 4,5 & 4,0 & 5,0 & 3,3 \\
\hline $\begin{array}{l}\text { ESBL Entero- } \\
\text { bacteriaceae }\end{array}$ & 66,6 & 42,5 & 72,5 & 55,5 & 29,3 & 35,5 & 22,2 & 25 & 24 & 30 & 33 & 25 \\
\hline FLU-R Candida & 15 & 15 & 22,5 & 10,2 & 5 & 8,25 & 5,0 & 6,0 & 10 & 6 & 5 & 5 \\
\hline CD4 (mean) & 55 & 121 & 182 & 201 & 198 & 355 & 320 & 406 & 350 & 370 & 401 & 395 \\
\hline
\end{tabular}

\section{References}

1. ARASON VA, KRISTINSSON KG, SIGURDSSON JA, STEFANSDOTTIR G, MOLSTAD S, GUDMUNDSSON S.: Do antimicrobials increase the carriage rate of penicillin resistant pneumococci in children? Cross sectional prevalence study. In BMJ. 1996, August 17, 313 (7054): 387-391

2. BIENERTOVÁ, J., RÜCKER, P. 2015: Sociální rehabilitace - Inkluze osob s disabilitou - iluze nebo realita? In: Rehabilitácia ISSN 0375-0922, Vol. 52, 2015, No 1, p. 57-64

3. MUSILOVÁ, E., SUROVČÍKOVÁ, Z. 2015: Sebestačnost' po pertrochanterickej fraktúre u seniorov. In: Rehabilitácia. ISSN 0375-0922, Vol. 52, 2015, No 1, p. 12 - 18

4. HUOVINEN P, MENNTYJARVI R, TOIVANEN P.: Trimethoprim resistance in hospitals. In BMJ (Clinical Res Ed). 1982 Mar 13; 284 (6318): 782-784

5. SEPPALA H, KLAUKKA T, VUOPIOVARKILA J, MUOTIALA A, HELENIUS
7. KRCMERY V, KALAVSKY E. 2007. Antibiotic and antifungal resistance in antibiotic „free" environment? Review, In Neurondocrinology Letters. 2007 Nov; 28, Suppl 3:33-4

8. SUN YS, ZHAO XY, ZHANG BK, JIANG JF, LU HJ, CAO YX, WU GZ, QIAN J, SUN YS, ZENG YJ: Practices and thinking of laboratory detection in the aid to West Africa to fight against Ebola. Bratislava Medical Journal Vol.117, No.5, p.254-257, 2016. doi:10.4149/BLL_2016_049.

9. PUTEKOVA S, KABATOVA O, MARTINKOVA J: Nursing problems in refugees. In Clinical Social Work, 2015, Vol. 2, p. 33-34.

10. WICZMANDYOVA D., MURGOVA A.: The life of diabetics, life with diabetes, Book. Clear Michalovce ISBN 978-809711629255.2012 , pp. 67

11. SILHAROVA B, SUVADA J, FRANEKOVA M, NOGE A, MIKOLASOVA G: $M a-$ laria in hyperendemic region, Neuroendcrinology Letters. 34, 2013, s1 38-43 